\section{Research Article}

(c) 2021 Wahyudi et al. This is an open access article licensed under the Creative Commons Attribution-NonCommercial 4.o International License (https://creativecommons.org/licenses/by-nc/4.o/)

Received: 15 July 2021 / Accepted: 7 October 2021 / Published: 5 November 2021

\title{
The Role of Social Capital in Handling Covid-19 at the Local Level in Indonesia
}

\author{
Wahyudi ${ }^{*}$ \\ Achmad Nurmandi ${ }^{2}$ \\ Salahudin 3 \\ Iradhad Taqwa Sihidi ${ }^{3}$ \\ 1Department of Sociology, Universitas Muhammadiyah Malang, Indonesia \\ 2Department of Government Affairs and Administration, Jusuf Kalla School of Government, Universitas \\ Muhammadiyah Yogyakarta, Yogyakarta, Indonesia \\ 3Department of Government Studies, Universitas Muhammadiyah Malang, Indonesia \\ *Corresponding Author
}

DOI: https://doi.org/10.36941/ajis-2021-0158

\section{Abstract}

The Covid-19 pandemic is a multidimensional problem that requires the government to be adaptive and creative in mobilizing all available resources. It's not just a matter of solutive policies, but more than that, social capital is needed because handling the Covid-19 crisis must involve the cooperation of all parties. This study aims to provide an analysis of how social capital works in handling Covid-19 in Blitar City, Indonesia. The focus is seeing response from Regional Apparatus Organizations (OPD) and community elements consisting of Covid Task Force, Community Organizations (Ormas), Community / Community Volunteers, $R T / R W$, and other components in the Blitar City community. This study shows that social capital in Blitar City works well. There is mutual trust and strengthen cooperation between the government and the people to come out of the crisis together. The City Government has succeeded in showing good responsiveness accompanied by coordination and cross-stakeholder communication, increasing trust in the government, and that is the key to public compliance with social mobility restrictions and recommendations for obeying health protocols. Although this compliance is not followed by all people, at least in general social solidarity has been formed which is the main key in handling the Covid-19 crisis.

Keywords: Covid-19, Social Capital, Public Policy; Regional government; Community

\section{Introduction}

At the end of 2019, precisely in December, the world was hit by a non-natural disaster which was marked by the emergence of a new type of virus called Covid-19/Corona originating from Wuhan City, China (Blühdorn and Deflorian, 2021). In the end, this virus managed to enter Indonesia. Through an official announcement delivered directly by President Joko Widodo, on March 2, 2020, two Indonesian citizens (WNI) domiciled in Depok were found to have contracted the SARS Cov-2 
virus, thus becoming the first case to occur. Since the first case was announced, the number of positive cases of Covid-19 has continued to increase. The government is increasing steps in dealing with the global pandemic from Covid-19.

The government has formed a task force to accelerate the handling of Covid-19, which is commanded by the Head of the National Disaster Management Agency (BNPB) Lt. Gen. TNI Doni Monardo. This task force will work effectively and synergize national and regional forces, involving ASN, TNI, and Polri, as well as involving support from the private sector, social institutions, and universities. This task force will mobilize integrated resources in handling the spread of this virus. The Task Force for the Acceleration of Handling Covid-19 has made four strategies that will consistently be carried out to strengthen the physical distancing policy as a basic strategy to overcome the Covid-19 pandemic (Salahudin, 2020). The first strategy as a strengthening of the basic strategy is the movement of masks for all campaigning for the obligation to wear masks when in public spaces or outside the home. The second strategy is contact tracing (tracing) of positive cases treated using rapid tests or rapid tests. Among them are the closest people, health workers who treat Covid-19 patients, as well as in the community in areas where many cases are found. The third strategy is education and preparation of independent isolation on some tracing results that show positive test results from rapid tests or negative with symptoms to self-isolate. The fourth strategy is hospital isolation which is carried out when self-isolation is not possible, such as because there are clinical signs that require definitive services at the hospital (Ansori, 2020).

The various strategies that have been made by the Central Government immediately received a response from the Regional Government through Covid-19 prevention activities. Even now, regions have used their autonomy rights by issuing circulars containing appeals to limit activities outside the home or what we call Contact Distancing, such as schools being closed, public places being closed, and even places of worship being restricted. It is hoped that the steps taken by each Regional Government are expected to cover four aspects, namely, prevention, response, recovery, and a work team that always conducts consultations on policy plans made to the Task Force for the Acceleration of Covid-19 Response (Machmud et al., 2020).

Currently, the stage of handling Covid-19 has entered a new phase called the New Normal. The implementation of public policies in the midst of the Covid-19 pandemic is not without obstacles; therefore, synergistic cooperation between the central and regional governments is very important. Togetherness and harmony of action with the Regional Government are very important. In the new normal era, people are faced with changing lifestyles, starting from the individual side to the social, cultural, economic, political, and legal levels. The PSBB policy taken by the Government has hampered public services. There is still a high tendency in the community to access public services directly, so the transition to a new normal needs to be accompanied by measures to provide education and massive socialization to all elements of society (Djalante et al., 2020).

The public needs to be encouraged to be literate in information technology and understand the consequences of the current digital era in order to be able to access public services online, especially during the new normal. Education on the Covid-19 health protocol also needs to be massively promoted through advertisements on television and various media as socialization to the public in facing the new normal. Excellent public services, especially health services, are a demand. Public services are an inseparable part of Bureaucratic Reform. The community must be served and pay attention to their health, especially the stunted and poor population (Salahudin, 2020).

The government is preparing the health sector as the front line in handling the pandemic. Increasing the preparedness of many hospitals and equipment is in accordance with international standards, including the budget specifically allocated for all prevention and treatment efforts. However, in its implementation, the Government is still focusing on policies on how to overcome and improve. As an example of the existing coping policies, it can be seen in the provision of assistance packages in the form of subsidies to the poor. The subsidy is given to ensure that they can still live normally even if they do not work directly. This step should be appreciated, given their vulnerability in the context of health and the economy. However, this step is considered not yet possible tackling 
the long-term impact of the Covid-19 pandemic (Abidin, Suryanto and Utami, 2020).

In this situation, the role of the Regional Government in dealing directly with the community in dealing with the COVID-19 non-natural national disaster seeks to take agile policies and provide a sense of security to the community. With the hope that the policies taken are truly mature and the people who guard them. Community involvement is needed because it is impossible for the government to solve the problem itself (kemenkes.go.id, 2020). A number of policies taken by the Regional Government in a relay are captured by the technical OPD through activities that are directly in contact with the community in terms of handling Covid-19. One example is the distribution of basic necessities to the poor. Activities that have been carried out in dealing with Covid-19 are still focused on resolving their impact on the economy and health. Actually, there are important things that actually become the main basis for rising from this pandemic as an effort to realize community resilience, namely the social and cultural fields that underlie people's behavior (Mahbub et al., 2020).

The description above illustrates that the government's response to Covid-19 is faced with many problems, including communication and coordination that have not been well developed, the slow response of local governments, and the collaboration of stakeholders has not been well established. These problems are related to two things, namely, the role of social capital and the government's response. Previous research has not analyzed the role of social capital and the government's response in handling Covid-19. This research is focused on analyzing the role of social capital and the response of local governments in handling Covid-19. Social capital is one of the capitals that can be developed and empowered as a force in dealing with and resolving the spread of Covid-19 in Indonesia. The use of social capital in handling the Covid-19 crisis is highly dependent on public awareness and the government as actors who play an important role in controlling the spread of Covid-19. Public and government awareness is related to the willingness of the community to trust each other, cooperate, collaborate, and synergize in realizing a common goal, namely minimizing and controlling the massive spread of Covid-19.

\section{Literature Review}

\subsection{Social capital concept}

Social capital has been known since the end of 1980. Social capital was introduced by Bourdieu (1989), in an article entitled The Forms of Capital (Dufhues, Buchenrieder, and Munkung, 2013). Bourdieu explains that social capital can be explained and converted to other capitals such as economic capital and cultural capital (Burke, Kraut, and Marlow, 2011). Bourdieu (1986), conceptualized three capitals, namely economic capital (money and property), cultural capital (goods and services, education), and social capital (relationships and networks) (Pisani and Micheletti, 2020). Coleman and Cardoso Sampaio, (2017), in an article entitled Social Capital in the Creation of Human Capital, introduces social capital as a conceptual means to understand the theoretical orientation of social action.

Social capital has two characteristics; namely, it is an aspect of the social structure and facilitates individual actions within the social structure. In this sense, the forms of social capital in the form of obligations and expectations, the potential for information, effective norms and sanctions, authority relations, and social organization can be used appropriately and give birth to a social contract. Social capital is mostly embedded in social networks and interactions that provide information and mutual support (Pisani and Micheletti, 2020). Putnam (1993), social capital as a value of mutual trust in the life of society and the state (Rayamajhee and Bohara, 2021). The pillars are networks, norms, and social trust that encourages social collaboration (coordination and cooperation) for the common good. Theoretically, there are social capital factors such as social networks, social trust, and shared goals (Partelow, 2021). 


\section{$2.2 \quad$ Trust-based network relations}

Social trust has an influence on social change and social events $(\mathrm{Wu}, 2021)$. Putnam (2004) social capital is a mutual trust between community members and the community towards their leaders. Social capital is defined as social institutions that involve networks, norms, and social trust that encourage social collaboration. Trust is a hope that grows in a society which is indicated by honest, orderly, and cooperative behavior based on shared norms. In the study of social capital, trust (trust/social trust) becomes dominant in various objectives in every capital development, which is based on a pattern of mutually supportive actions and can help build more cooperative social relations (Putnam, 2004).

The importance of trust greatly affects activities in an organization and institution (Wu, 2021). The existence of mutual trust that develops in the community has the opportunity to give birth to voluntary associations to be active and participate. Trust can be formed through community membership, relationships, networks, and alliances (Rayamajhee and Bohara, 2021). Social capital plays a very important role in the functioning and strengthening of modern society. Social capital is a condition that must be met for human development, economic development, social, political, and democratic stability.

Network relations are one of the factors of social capital. The network of relationships that are built makes it easier for social relations to run well. If social relations do not go well, it will affect social trust and affect the relational dimension of social capital (Bamford et al., 2020). Trust-based networks can be utilized as a measure of influence to drive decision-making processes and recommendation mechanisms in complex social networks (Chaker and Impedovo, 2021). Coordination as the basis for reciprocal relationships that allow for mobilizing and linking social capital, facilitating collective action aimed at the benefit of society (Sarma and Pais, 2008). Multistakeholder networks have a positive impact on global issues and also contribute to social capital such as relational trust (Sarma and Pais, 2008). So, in the study of a pandemic such as a coronavirus also requires a study of social capital.

\subsection{Information and social networks}

The study of social capital has expanded to various topics so that social capital can also be studied through several other aspects, such as the exchange of information (Kikuchi and Coleman, 2012). The relationship of social capital with information and also social networks is seen as a success factor for social capital in building electronic-based networks (Sommer and Gamper, 2021). Information is a social need. Therefore, in most cases, the situation is resolved through an interaction in a social network (Bartscher et al., 2020).

Coleman (1988), explains the importance of a smooth flow of information within the social structure to encourage the development of activities in society. In informing a social network, a communication space is needed to grow the information on the network between individuals and other groups so that it gives birth to trust in the community. In facilitating the flow of information and communication, networks are needed, which may have many contributions to the sustainable development of social capital, such as the emergence of cyber networks or online social networks (Huysman and Wulf, 2006).

Online-based social networks are becoming increasingly popular and are used as a means for various activities in social life (Partelow, 2021). Therefore, the participation of individuals involved in interactions and networks can generate profits. In general, three reasons can be offered why the existing capital in social networks contributes to increasing the results of actions, including the flow of information, social ties, and resources $(\mathrm{Wu}, 2021)$. Hance, the communication space can foster social trust and provide opportunities for the community to be more participatory and increase collective interest (Bamford et al., 2020). 


\section{$2.4 \quad$ Norm and trust crisis}

Social norms are also an important factor of social capital (Putnam, 2004). Norms have become important entities that are considered and can regulate and coordinate actions and behavior and have a direct impact on the achievement of goals $(\mathrm{Wu}, 2021)$. When a crisis occurs, it certainly requires a shared responsibility within the community (Partelow, 2021); therefore, an effort is needed to build social trust, one of which is by paying attention to social norms (Rayamajhee and Bohara, 2021). Coleman (1990), argues that in the absence of norms that are agreed upon and obeyed by the community, what arises is a state of anomie where everyone tends to act according to their own will without feeling any ties to others.

Putnam (1993), also explains that social norms consist of understandings, values, expectations, and goals that are believed and carried out together by a group of people. These norms can be formed from religion, moral guidelines, or standards such as codes of ethics in the form of preconditions or products of social beliefs. Meanwhile, Fukuyama (2015) says that trust arises when people both have a set of moral values that are adequate to foster behavior in society. Applicable social norms can also be a factor in the enactment of a public policy that is expected to change social behavior and also a belief $(\mathrm{Wu}, 2021)$. In another study, such as the World Happiness Report research also argues that a regulation greatly affects public trust. More effective regulation by the state can help to provide trust in interpersonal trust (Bamford et al., 2020). Social trust is a form of desire to take risks in social relationships based on the hope that others will also participate in a pattern of mutually supportive actions (Putnam, 2002). Trust is a hope that grows in a society which is indicated by honest, orderly, and cooperative behavior based on shared norms (Fukuyama, 1995). Social trust is a form of desire to take risks in social relationships based on the hope that others will also participate in a pattern of mutually supportive actions (Putnam, 2002). Trust is a hope that grows in a society which is indicated by honest, orderly, and cooperative behavior based on shared norms (Fukuyama, 1995). Social trust as a form of willingness to take risks in social relationships based on the hope that others will also participate in a pattern of mutually supportive actions (Putnam, 2002). Trust is a hope that grows in a society which is indicated by honest, orderly, and cooperative behavior based on shared norms (Fukuyama, 1995).

\subsection{Government response to Covid-19}

The high risk and transmission of Covid-19 require the government to increase attention and introduce strategic steps in controlling and supervising public health (Harapan et al., 2020). public health related to this Covid-19 disease (Wajdi et al., 2020). The role of the government also needs support from non-government stakeholders to collaborate and synergize together in improving the readiness of facilities and also the availability of health services (Wajdi et al., 2020); collaborate (Setiati and Azwar, 2020). But in handling Covid-19, the government needs to take strategic policies to respond to the spread of Covid-19 through regulations and strengthen government institutions (Djalante, 2018).

Countries affected by Covid-19 evaluate policies to avoid transmission and new cases, such as closing public facilities, working from home, stopping public transportation operations, and taking lockdown measures (Patrikar et al., 2020), India and Kenya implement the same thing. Kenya is working with hospitals to limit hospital visits (Aluga, 2020). Adaptation to emergency conditions requires appropriate steps. Covid-19 requires the government to adapt and behave in society, such as Indonesia taking the first step in setting policies (Djalante, Lassa, et al., 2020), India doing a lockdown for two to three weeks (Lamba, 2020), controlling the transmission of Covid-19 with medication traditional (Xiao and Torok, 2020).

The USA, in dealing with Covid-19 accelerated the preparation process at the health system level by regulating the public response, but the response was not optimal (Loungani et al., 2020); besides the impact of transmission caused a very rapid increase in cases and had a significant impact on the 
readiness of health workers (Chen et al., 2020). The government needs to respond to Covid-19 by identifying gaps and government readiness in responding to the pandemic by looking at what happened in Italy (Duarte Alonso et al., 2021). While the government's social distancing policy has not been able to suppress the spread of the epidemic, even the social distancing policy is considered an uncertain policy (Galvin, Fernandez-Luque, and Li, 2020). Saudi Arabia imposed a ban on worship for and visited to mosques with a policy issued on February 28, Saudi Arabia has banned travel to countries affected by SARS-CoV-2 (Algaissi et al., 2020). This decision will not only reduce the risk of importing SARS-CoV-2 to other countries but also prevent cases from being exported to other countries. Singapore responded by tightening health services in 1700 hospitals so that positive numbers can be handled quickly ( $\mathrm{Wu}, 2021)$.

Putri and Anulus (2020) the government needs to carry out policies in a fast period of time, such as; social distancing, physical distancing, learn from home, work from home. Or worship at home, use personal protective equipment, wash hands (Zaharah, Kirilova and Windarti, 2020). The spread of the virus results in changes in people's lifestyles and is not ready to adapt (Zaharah et al., 2020). In the case of Indonesia, the government did not implement a lockdown policy like other countries and adopted a large-scale social restriction policy (Calvin, 2020). Along with the Covid-19 prevention and mitigation policies, conflicts emerged in the midst of a pandemic originating from central and regional government policies (Ansori, 2020) so that the handling of Covid-19 was faced with government political problems. To prevent this the government needed to improve coordination and issue appropriate policies (Djalante, Lassa, et al., 2020).

\section{Methodology}

This study uses a survey approach on stakeholder opinions about the role of social capital and the local government's response to Covid-19 in Blitar City, Indonesia. This study aims to see the response of Regional Apparatus Organizations (OPD) and community elements consisting of: Covid Task Force, Community Organizations (Ormas), Community / Community Volunteers, RT / RW and other components in the Blitar City community.

Several things were asked from this questionnaire to see how far the handling of COVID-19 has been in Blitar City. There are several variables explored, including the role of Social Capital that supports the handling of Covid-19; Policies and Activities for Handling Covid 19; Impact of Covid 19 Handling Policies and Activities; Programs and Activities that Support Public Resilience during Covid-19; and Covid-19 Handling Problems.

The number of respondents who filled out this online questionnaire was 119 people from different backgrounds. Most of those who filled out the questionnaire were representatives of the Blitar City Government OPD with a percentage of 6o\%, while the Covid-19 Task Force and elements of the community were $5 \%$. It can be seen in full in Graph 1 and Graph 2 below.

- Local Govemment Officials

- Society Organisation

- Covid- 19 Team Official

= Communities

- Society People

- Local Representative Officials

- Community Officials

- District Officials

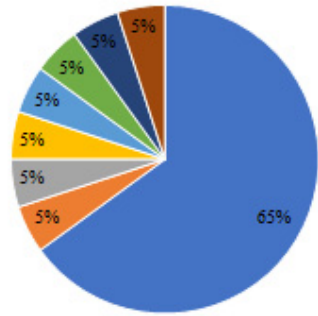

Graph 1. Number and Background of Respondents. 
Refer to the data, from the number of respondents as many as 119 above. Most of the respondents were male by $55.5 \%$ and $44.5 \%$ for female respondents.

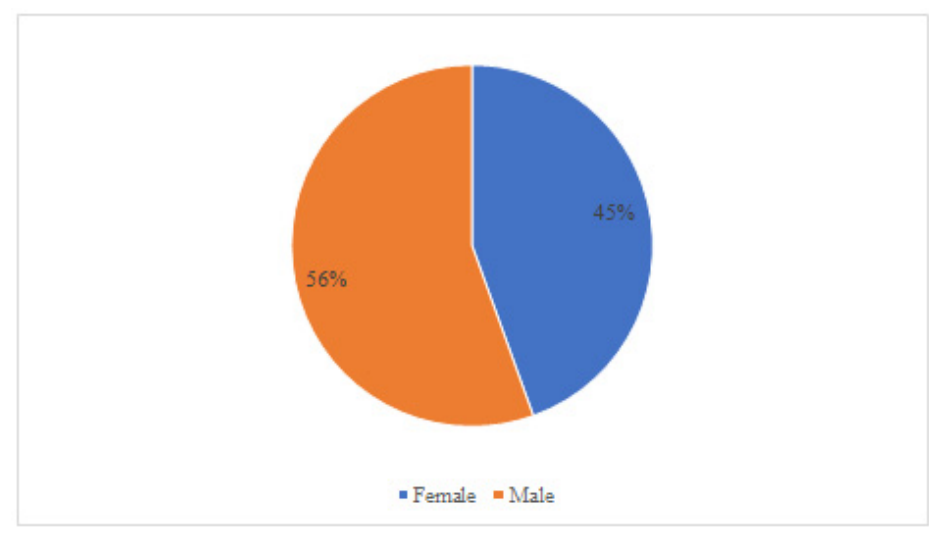

Graph 2. Respondents by Gender.

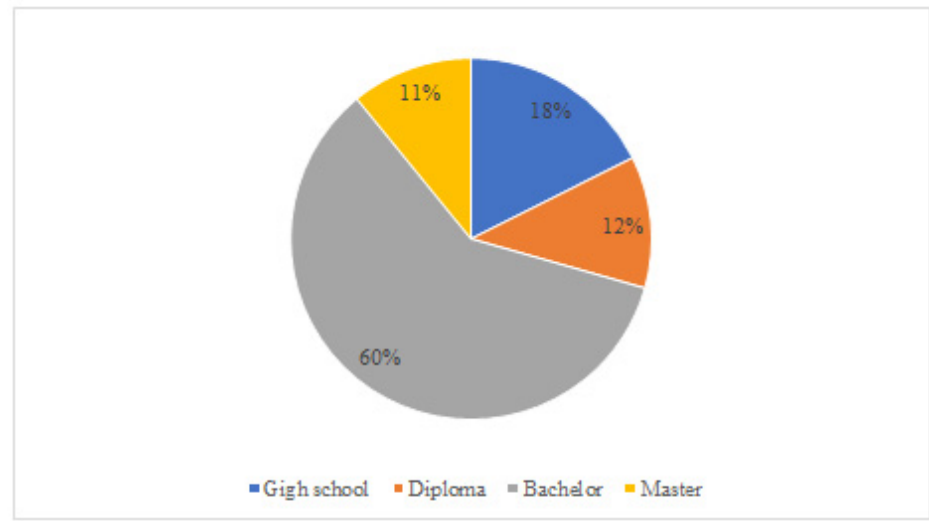

Graph 3. Respondents Based on Education Level

Based on the education level of each respondent, it can be seen the distribution of respondents, namely: 60\% who are Bachelor, $18 \%$ High School, $12 \%$ Diploma and respondents who take the master's level, which is $11 \%$ (Graph 3).

\section{Research Result}

The handling of Covid-19 is a serious concern by the Blitar City government; this can be seen from the response given by the Blitar City Government when the government issued an announcement that the Covid-19 pandemic was an Extraordinary Event (KLB) on March 3, 2020. Several rules were prepared as a legal umbrella in handling the COVID-19 pandemic-Covidis in Blitar City. In addition to handling health, the current pandemic requires handling from many approaches and perspectives, one of which is social capital. The online survey questionnaire that was distributed tried to see a picture related to the identification of social capital in Blitar City in handling Covidig. 


\subsection{The role of Social Capital that supports the handling of Covid-19}

Policies and steps taken by various countries in responding to the Covid-19 pandemic are by setting policies that are getting stricter from time to time. However, public trust is not always linear with public compliance with government policies related to Covid-19 prevention. The solution to overcome this problem is through the activation of social capital, namely community participation through innovation and social solidarity.

Based on the results of a survey related to public attitudes and perceptions regarding the handling of Covid-19 in Blitar City, it is shown that cooperation and mutual trust between stakeholders are very important in dealing with Covid-19 with a percentage of $96 \%$. Therefore, the public must trust the Covid-19 disaster management policy scheme, and the government maintains public trust by optimizing efforts to overcome the Covid-19 pandemic. Then, opinions related to the Blitar City Government in collaboration with religious, cultural, and community leaders in dealing with Covid-19, the Blitar City Government trying to involve citizens (communities) in dealing with Covid-19, and the Blitar City Government understanding and implementing the policy of obtaining a high percentage. The same, which is $91 \%$. In this case, The power of groups and networks plays a role in strengthening the mental immunity of the community by building individual awareness in community groups to break the chain of spreading the Covid-19 virus. As seen in the Figure 1 below.

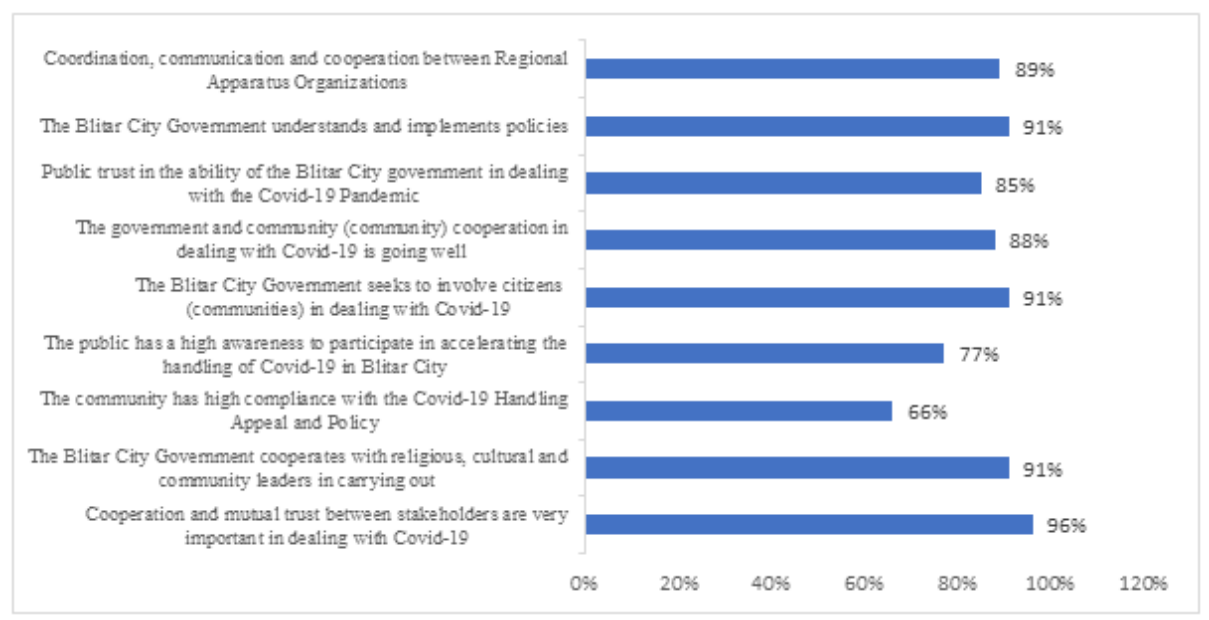

Figure 1. Identify the Role of Social Capital that supports the handling of Covid-19.

The next public opinion is coordination, communication, and cooperation between Regional Apparatus Organizations with a percentage of $89 \%$. The government and community (community) cooperation in dealing with Covid-19 went well, earning a percentage of $88 \%$. Public confidence in the ability of the City of Blitar in dealing with the Covid-19 pandemic is quite high at $85 \%$. The public has a high awareness to accelerate the handling of Covid-19 in Blitar City, obtaining 77\%. Public compliance with appeals and policies for handling Covid-19 is a fairly serious problem; this can be seen from the responses of respondents who stated that it was $66 \%$ and was the lowest value compared to other problems.

\subsection{Policies and Activities for Handling Covid-19}

The Covid-19 pandemic can no longer be handled partially or individually and sectorally. Therefore, all policies in the regions must be in accordance with and within the corridors of laws, government 
regulations, presidential decrees, presidential instructions, and other relevant laws and regulations, although regional innovations can be carried out as long as they are within the corridors of central policies and statutory regulations.

In general, the Blitar City Government's policies regarding data and information updates on handling Covid-19 in real-time obtained the highest percentage of public opinion, which was 94\%. Disclosure of data related to Covid-19 in Blitar City is a platform that will be a reference in formulating and evaluating various policies in the context of dealing with Covid-19 and increasing public awareness in dealing with the Covid-19 pandemic. The next highest public opinion is related to the Blitar City Government having regulations/policies for handling Covid-19 of 91\%. The regulations/policies implemented in handling Covid-19 are refocusing the budget and distributing various aids to residents affected by Covid-19. The next public opinion is that the Blitar City Government makes policies for handling Covid-19 that are responsive and adaptive to the problems that occur in the field by $88 \%$ (Figure 2). This means that the Blitar City Government has made policies that are right on target and answer problems related to the Covid-19 outbreak.

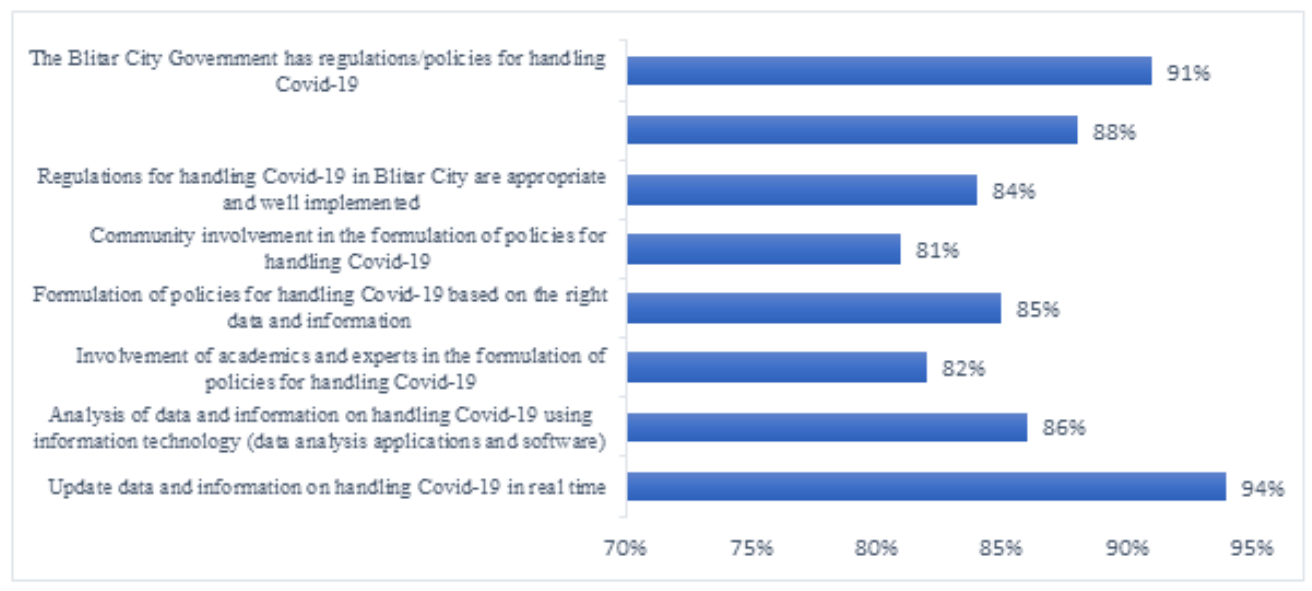

Figure 2. Identification of Policies and Activities for Handling Covid 19.

Public opinion regarding data analysis and information on handling Covid-19 using information technology (data analysis applications and software) is $86 \%$. The formulation of the Covid-19 handling policy based on the right data and information obtained a percentage of the vote of $85 \%$. The Blitar City Government has guarded information about Covid-19 in a precise and accurate manner. The source of information comes from the voluntary initiative of pro-data Blitar City citizens, consisting of health practitioners, academics, and professionals. With the accuracy of the information, public opinion regarding the regulation for handling Covid-19 in Blitar City is appropriate and well implemented and has also received a positive response, which is $84 \%$. Meanwhile, the involvement of academics and experts in the formulation of Covid-19 handling policies obtained a percentage of $82 \%$ (Figure 2 ).

\subsection{Impact of Covid 19 Handling Policies and Activities}

The Covid-19 pandemic has hit almost all sectors in the Blitar City area. The impact is felt not only in the health sector but in other fields such as economics, social culture, education. The City Government has also made great efforts in dealing with the Covid-19 pandemic, one of which is through the establishment of regulations/policies. The effectiveness of policies and activities for 
handling Covid-19 in Blitar City has generated various public opinions, including in handling Covid19 activities, the community considers it necessary to increase public compliance with health protocols for handling Covid-19 by $98 \%$ (Figure 3). Similarly, the opinion of the public is $98 \%$ stating that regulations/policies need to provide peace/comfort for the public. This means that policy recommendation in the form of programs, action plans, as well as behavioral guidelines that are invested in increasing mental capacity, especially behavior in order to achieve the level of community compliance with health protocols. Thus, through this policy, it is able to prevent the worsening of the Covid-19 pandemic situation and provide peace for the community.

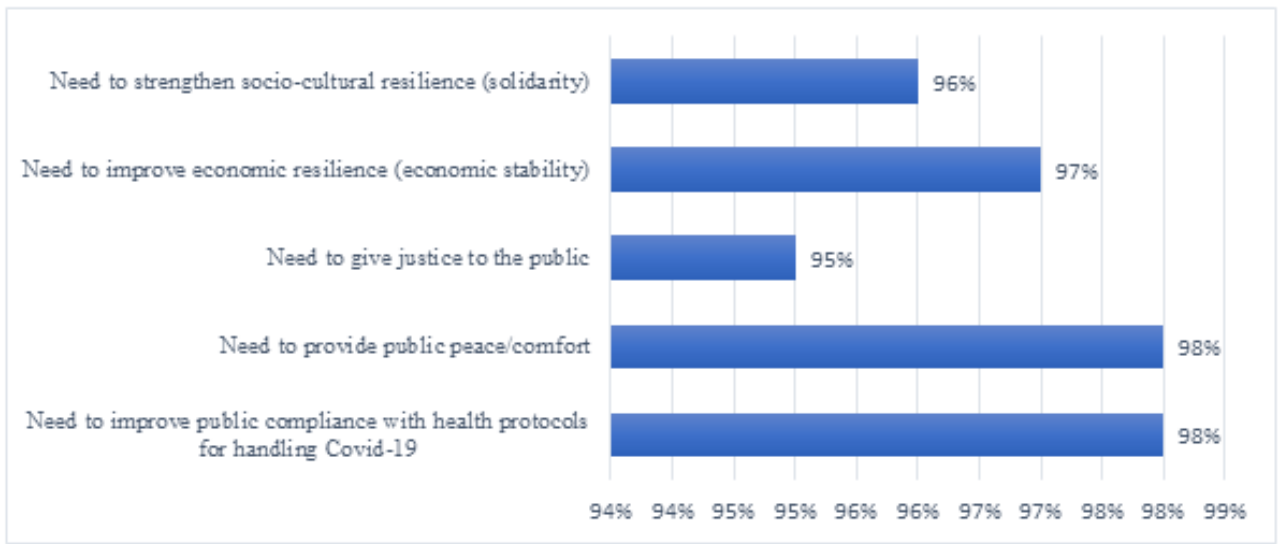

Figure 3. Impact of Covid 19 Handling Policies and Activities.

The next public opinion relates to the need to increase resilience and the economy (economic stability) by $97 \%$. Since the implementation of the new normal policy in Blitar City, the community hopes that the recovery of economic conditions will begin to creep up and stabilize again. Then, the public perception of the regulations/policies of the Blitar City Government is that it is necessary to strengthen socio-cultural resilience (solidarity) by $96 \%$. Social solidarity needs to be fostered at the individual and local community levels in accordance with their respective local wisdom. With social solidarity, people are finally willing to obey the government's appeal and donate some of their ability to help others for the common good. At the same time, the public opinion related to the need to bring justice to the public is $95 \%$ (Figure 3 ).

\subsection{Programs and Activities that Support Public Resilience during Covid-19}

Facing the current new normal era, the Blitar City Government must be able to prepare programs and activities that will be carried out to deal with the post-Covid-19 pandemic. If you refer to the questionnaire, there are several programs and activities that are considered important for the further handling of COVID-19. In this case, it can be seen in the following figure 4 . 


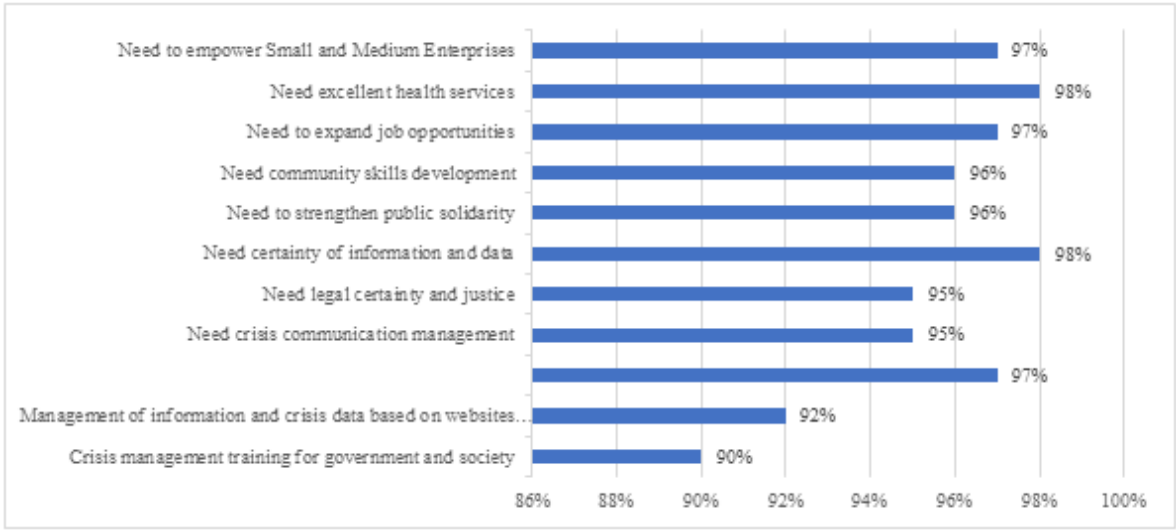

Figure 4. Identification of Programs and Activities that Support Public Resilience during Covid-19.

Based on the opinions given by respondents, it can be seen that excellent health services are the programs and activities that received the greatest response, namely $98 \%$ stating that excellent service is very much needed in handling Covid-19 in Blitar City. Especially when referring to current data, Covid-19 cases are increasing, Blitar City is experiencing an increase in cases. In line with the improvement of health services, the certainty of information and data is also an integral part of increasing public awareness, and accurate information also provides peace for the community, $98 \%$ of respondents stated this in the survey conducted.

Programs and activities that are considered important and according to large respondents are related to the role of the Covid-19 task force with a percentage value of $97 \%$. Other programs and activities that get similar scores are related to the empowerment of MSMEs and job expansion. It is known that the Covid-19 pandemic has brought changes to society, one of which is that many business fields have to reduce workers, and the impact that is felt the most is the slumping MSMEs. These two things are important for the Blitar City Government to be able to revive the informal sector so that the economy can bounce back and can increase employment opportunities.

Apart from the programs and activities discussed above, other forms of activity can be seen, including: 1) crisis communication management $(95 \%) ; 2$ ) legal certainty and justice enforcement $(95 \%)$; 3) community skills development $(96 \%)$; 4) crisis management and data that is easily accessible to the public (web-based) (92\%) and 5) government and community crisis management (90\%). These programs and activities are important in handling Covid-19.

\subsection{Covid-19 Handling Problems}

The Covid-19 pandemic that came unexpectedly presented problems as well as challenges for individuals and organizations to handle. There is no exact model for each country, and the characteristics of the problems in each place are different. In this section, based on the results of the questionnaire given, there are problems that can be identified related to the handling of Covid-19, including low community compliance and overlapping policies between the center and the regions. During the early days of the Covid-19 pandemic, the central government was seen "stuttering" in responding to the Covid-19 pandemic. The flow of unorganized coordination and between the policies made between the center and the regions experience overlaps.

The issue of Covid-19 is suspected to be the result of a conspiracy spreading in the community; this irresponsible issue also has a big impact on the community. The impact felt is that people are indifferent because they feel that this pandemic is just a conspiracy; the resistance given by the community is also getting bigger because the Covid-19 pandemic has changed people's habits. This is 
illustrated in the survey results, $34 \%$ of respondents stated that other problems that emerged in full could be seen in Figure 5 below.

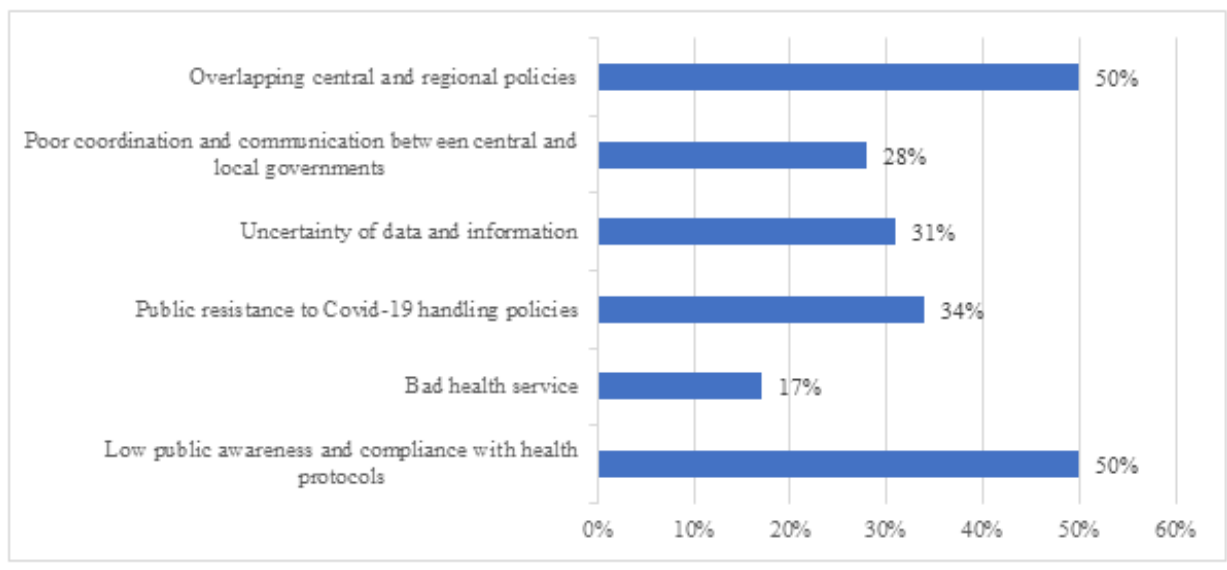

Figure 5. Covid-19 Handling Problems.

Based on the data above, it can be seen that other problems related to the handling of Covid-19 are related to the uncertainty of data and information (31\%), poor coordination as discussed above, namely $28 \%$ stating this, and health services that are still felt to be lacking by $17 \%$. . The health services in Blitar City based on the results of this survey are considered good because only a few consider the health services in Blitar City to be bad.

From the explanation of the results of this survey, it can be seen that according to the OPD and elements of society in Blitar City, the handling of Covid-19 in this city is running according to an organized and well-coordinated workflow. The Acting Mayor's directive is the umbrella for every activity in Blitar City. This is certainly a good example and good performance for the Blitar City government. In line with this, from the opinion that was built in the community, the Blitar City Government was able to answer the challenges of the impact of the Covid-19 pandemic.

\section{Discussion}

The results of this research survey reveal that social capital plays an important role in handling Covid-19 in Blitar City. Cooperation and mutual trust between stakeholders are seen as part of social capital that needs to be put forward in dealing with Covid-19. A number of previous studies reveal the same thing, namely, cooperation and mutual trust are the keys to success in dealing with crises such as Covid-19 (Rayamajhee and Bohara, 2021). Cooperation is related to the role of stakeholders in dealing with the Covid-19 crisis, which is adjusted to their respective capacities. Stakeholder cooperation is implemented through the efforts of the central government to make regulations regarding the handling of Covid-19, which are then implemented jointly by local governments and the community at lower levels. Cooperation needs to be supported by mutual trust between stakeholders. Mutual trust is the key to building cooperation between stakeholders. Mutual trust in dealing with Covid-19 is built through openness and fairness in formulating and implementing policies for handling Covid-19 at lower levels ( $\mathrm{Wu}$, 2021). Furthermore, cooperation and mutual trust affect communication and coordination between stakeholders that go well in dealing with Covid-19.

The Blitar City Government in dealing with Covid-19 is supported by the availability of available information and data realtime to make the public aware of the development of Covid-19 cases in Blitar City. High data accuracy like this can increase public awareness while at the same time being 
able to independently take precautions. In addition, the accountability shown by the city government will increase trust in the crisis management policies that are made. Legitimacy is an important instrument in the operationalization of social capital because the government, with its various policy interventions, is considered capable of bringing people out of the crisis (Bartscher et al., 2020). The growing and strengthening prestige in the midst of the crisis has made it easier for the Blitar City government to carry out activities to limit social mobility, enforce health protocol discipline and build solidarity in the midst of the Covid-19 situation.

From the survey data that has been carried out, the key lies in the use of social capital formed through a participatory approach. The involvement of key actors other than the Blitar city government, which in this case coordinates and communicates with relevant stakeholders, will further increase social cohesiveness because policies are made based on a common consensus that represents common interests. Such a deliberative model will increase social solidarity which, of course will make the resulting policy effective (Putnam, 2004).

Efforts to embrace civil society groups such as NU, Muhammadiyah, and cultural groups also play an important role in the implementation of social capital. These organizations have a large following and become opinion leader so that the instructions and directions given are quite influential at the lower levels. Several religious activities which became one of the crowd centers were successfully suspended following the instructions issued by these two religious organizations. Of course, this is not an easy job considering that worship or religious activities such as congregational prayers and recitations are very important in the people of Blitar City. This kind of sacrifice is an expression of the social solidarity of the community for the common good.

Social capital is a sign that there is a common interest for the safety of the entire community of Blitar City behind several Covid-19 handling strategies carried out by the City government. City government performance is so good because it is considered responsive and adaptive. The openness of data, collaboration with the community, excellent health care, and the accuracy in helping the most affected groups (small communities) through budget refocusing as outlined in several social assistance schemes is considered very good by the community (Fukuyama, 2015). With that, the community finally wants to work together to successfully handle Covid-19, especially in enforcing health protocols in daily activities.

However, the work of social capital is also not fully followed by the community. From the survey conducted, although trust and confidence in the Blitar City government to deal with Covid-19 is very high, it is not necessarily linear with people's behavior. In the field, there are still people who ignore the call for implementing health protocols (Machmudet al., 2020). Denial like this shows the weak commitment of some people to the common interest. This kind of selfishness can be determined by ignorance or lack of awareness of the dangers of Covid-19.

\section{Conclusion}

Maximizing social capital is one of the important keys that must be pursued so that effectivenessCovid19 case-control. There is a relationship of mutual trust and support between the community and the government. Several social restriction policies and enforcement of health protocols issued by the government are enough to be followed by people who show strong sense of crisis. This predicate makes people obey the rules because it is believed to guide them out of the Covid-19 crisis.

Social capital is formed through a fairly long process. Reflecting on the case in Blitar City, satisfaction with the government's leadership and collaboration with several civil society groups has existed before. In several activities, the City Government cooperates with several communities and community organizations. This pattern has been intensified in the Covid-19 era and has succeeded in increasing mutual trust between the government and the community. The existence of communication and the involvement of public/community participation in crisis management indicates an ongoing democratic process. There is a common consensus resulting from the Covid-19 handling strategy, which makes its implementation in the field even easier. 
This is where the role of the government as a maker and enforcer of regulations/policies is very crucial. The government is obliged to show strong leadership so that people believe and are willing to sacrifice one of their human rights, namely freedom. In some areas, the lack of public awareness is the cause of the difficulty of the effectiveness of the Covid-19 handling strategy, especially social restrictions and enforcement of health protocols. This is a very serious problem considering that without public compliance, it is impossible for the government to solve Covid-19. Therefore, the city government must be able to produce the right policy innovations through effective public communication.

From the case in Blitar, social capital is a very important instrument in handling the Covid-19 problem. This power must be managed properly. The government really needs to make appropriate crisis management policies, for example, providing protection to vulnerable groups through social assistance and continuing to build coordination and communication with community groups. The public also needs to continue to support all efforts to deal with Covid-19 through compliance with the prohibitions and recommendations made by the government. This crisis is indeed long and very tiring which cannot be passed without good cooperation between the government and the community.

\section{References}

Abidin, Suryanto, T. \& Utami, P. (2020) 'Beyond muamalah principles in digital payment education and its impacts on corruption prevention in indonesian public sectors', Journal of Social Studies Education Research. Institut Agama Islam Negeri (IAIN) Palu, Indonesia: Association for Social Studies Educa, 11(3), pp. 46-64. Available at: https://www.scopus.com/inward/record.uri?eid=2-s2.o8509180444o\&partnerID=40\&md5=dcbbdbfooc42ce9574b66ao4e 4 b53662.

Algaissi, A. A. et al. (2020) 'Preparedness and response to COVID-19 in Saudi Arabia: Building on MERS experience', Journal of Infection and Public Health. King Saud Bin Abdulaziz University for Health Sciences, 13(6), pp. 834-838. doi: 10.1016/j.jiph.2020.04.016.

Aluga, M. A. (2020) 'Coronavirus Disease 2019 (COVID-19) in Kenya: Preparedness, response and transmissibility', Journal of Microbiology, Immunology and Infection. Elsevier Taiwan LLC, 2019(April), pp. 2019-2021. doi: 10.1016/j.jmii.2020.04.011.

Andrikopoulos, S. \& Johnson, G. (2020) 'The Australian response to the COVID-19 pandemic and diabetes lessons learned', Diabetes Research and Clinical Practice. Elsevier B.V., 165, p. 108246. doi: 10.1016/j.diabres.2020.108246.

Ansori, M. H. (2020) 'Assessing and Mitigating Conflicts amidst the COVID-19 Pandemic in Indonesia', The Insights, 16(4).

Bamford, J. et al. (2020) 'Social Capital and Mental Health Among Black and Minority Ethnic Groups in the UK', Journal of Immigrant and Minority Health. Springer US. doi: 10.1007/s10903-020-01043-o.

Bartscher, A. K. et al. (2020) 'Social capital and the spread of Covid-19: Insights from European countries', ECONtribute Discussion Paper, (oo7).

Blühdorn, I. \& Deflorian, M. (2021) 'Politicisation beyond post-politics: new social activism and the reconfiguration of political discourse', Social Movement Studies. Institute of Social Change and Sustainability (IGN), WU Vienna, Vienna, Austria: Routledge. doi: 10.1080/14742837.2021.1872375.

Bourdieu, P. (1989) The Field of Cultural Production. Columbia University Press.

Burke, M., Kraut, R. \& Marlow, C. (2011) 'Social capital on Facebook: Differentiating uses and users', Conference on Human Factors in Computing Systems - Proceedings, pp. 571-580. doi: 10.1145/1978942.1979023.

Calvin (2020) 'Handling Covid-19 Related To Regional Security According To Asean Political-Security Community', Lex Scientia Law Review, 4(1), pp. 19-32. doi: https://doi.org/10.15294/lesrev.v4i1.38195.

Chaker, R. \& Impedovo, M. A. (2021) 'The moderating effect of social capital on co-regulated learning for MOOC achievement', Education and Information Technologies. Education and Information Technologies, 26(1), pp. 899-919. doi: 10.1007/s10639-020-10293-2.

Chen, H. et al. (2020) 'Clinical characteristics and intrauterine vertical transmission potential of COVID-19 infection in nine pregnant women: a retrospective review of medical records', The Lancet. Elsevier Ltd, 395(10226), pp. 8o9-815. doi: 10.1016/So140-6736(20)3036o-3.

Coleman, S. \& Cardoso Sampaio, R. (2017) 'Sustaining a democratic innovation: a study of three e-participatory budgets in Belo Horizonte', Information Communication and Society, 20(5), pp. 754-769. doi: 10.1080/1369118X.2016.1203971. 
Djalante, R. (2018) 'Review article: A systematic literature review of research trends and authorships on natural hazards, disasters, risk reduction and climate change in Indonesia', Natural Hazards and Earth System Sciences. United Nations University, Institute of Environment and Human Security, Bonn, 53117, Germany: Copernicus GmbH, 18(6), pp. 1785-1810. doi: 10.5194/nhess-18-1785-2018.

Djalante, R. et al. (2020) 'Review and analysis of current responses to COVID-19 in Indonesia: Period of January to March 2020', Progress in Disaster Science, 6, p. 100091. doi: 10.1016/j.pdisas.2020.100091.

Duarte Alonso, A. et al. (2021) 'Facing and responding to the COVID-19 threat - an empirical examination of MSMEs', European Business Review. School of Management, Curtin Business School, Curtin University, Bentley, Australia: Emerald Group Holdings Ltd. doi: 10.1108/EBR-09-2020-0231.

Dufhues, T., Buchenrieder, G. \& Munkung, N. (2013) 'Social Capital and Market Imperfections: Accessing Formal Credit in Thailand', Oxford Development Studies, 41(1), pp. 54-75. doi: 10.1080/13600818.2012.753999.

Fukuyama, F. (2015) 'Political order and political decay: from the industrial revolution to the globalization of democracy. By Francis Fukuyama', International Affairs, 91(1), pp. 171-172. doi: 10.1111/1468-2346.12193.

Galvin, C. J., Fernandez-Luque, L. \& Li, Y.-C. (Jack) (2020) 'Accelerating the global response against the exponentially growing COVID-19 outbreak through decent data sharing', Diagnostic Microbiology and Infectious Disease. Elsevier Inc, p. 115070. doi: 10.1016/j.diagmicrobio.2020.115070.

Harapan, H. et al. (2020) 'Coronavirus disease 2019 (COVID-19): A literature review', Journal of Infection and Public Health. King Saud Bin Abdulaziz University for Health Sciences, 13(5), pp. 667-673. doi: 10.1016/j.jiph.2020.03.019.

Huysman, M. \& Wulf, V. (2006) 'IT to support knowledge sharing in communities, towards a social capital analysis', Journal of Information Technology, 21(1), pp. 40-51. doi: 10.1057/palgrave.jit.2000053.

kemenkes.go.id (2020) Cegah Penyebaran Covid-19, Pelayanan Kesehatan Dilakukan Melalui Telemedicine, Kementerian Kesehatan Indonesia. Available at: https://www.kemkes.go.id/article/view/2004300ooo2/cegah-penyebaran-covid-19-pelayanan-kesehatandilakukan-melalui-telemedicine.html (Accessed: 14 June 2020).

Kikuchi, M. \& Coleman, C. Lou (2012) 'Explicating and Measuring Social Relationships in Social Capital Research', Communication Theory, 22(2), pp. 187-203. doi: 10.1111/j.1468-2885.2012.01401.x.

Lamba, I. (2020) 'Why India needs to extend the nationwide lockdown', American Journal of Emergency Medicine. Elsevier Inc., (xxxx), pp. 1-2. doi: 10.1016/j.ajem.2020.04.026.

Loungani, R. S. et al. (2020) 'A care pathway for the cardiovascular complications of COVID-19: Insights from an institutional response', American Heart Journal. Elsevier Inc., 225, pp. 3-9. doi: 10.1016/j.ahj.2020.04.024.

Machmud, M. et al. (2020) 'Government Response and Communication in Covid-19 Crisis Management in Indonesia', International Journal of Innovation, Creativity and Change, 14(2), pp. 377-396. Available at: https://www.ijicc.net/images/Vol_14/Iss_2/14226_Machmud_2020_E_R.pdf.

Mahbub, M. et al. (2020) 'Humanistic and mental health behaviorism in shaping the learning process in covid-19 outbreak', International Journal of Pharmaceutical Research. Institut Agama Islam Negeri Surakarta, Indonesia: Advanced Scientific Research, 12(4), pp. 3535-3539. doi: 10.31838/ijpr/2020.12.04.483.

Partelow, S. (2021) 'Social capital and community disaster resilience: post-earthquake tourism recovery on Gili Trawangan, Indonesia', Sustainability Science. Springer Japan, 16(1), pp. 203-220. doi: 10.1007/s11625-0200o854-2.

Patrikar, S. et al. (2020) 'Projections for novel coronavirus (COVID-19) and evaluation of epidemic response strategies for India', Medical Journal Armed Forces India. Elsevier Ltd, (xxxx), pp. 1-8. doi: 10.1016/j.mjafi.2020.05.001.

Pisani, E. \& Micheletti, S. (2020) 'Social capital and rural development research in Chile. A qualitative review and quantitative', Journal of Rural Studies. Dep. Territorio e Sistemi Agro-Forestali (TESAF), Università degli Studi di Padova (Italy) Viale dell'Università, Legnaro (PD), 15 - 35020, Italy: Elsevier Ltd. doi: 10.1016/j.jrurstud.2020.08.002.

Putnam, R. D. (2004) Democracies in Flux: The Evolution of Social Capital in Contemporary Society, Democracies in Flux. doi: 10.1093/0195150899.003.0001.

Putri, S. I. \& Anulus, A. (2020) 'Preventive actions to minimizing the coronavirus disease 19 ( COVID-19) transmissions among health workers : a systematic review', Journal of the Medical Sciences, 52(3), pp. 110-119. doi: http://dx.doi.org/10.19106/JMedSciSIoo5203202012.

Rayamajhee, V. \& Bohara, A. K. (2021) 'Social capital, trust, and collective action in post-earthquake Nepal', Natural Hazards. Springer Netherlands, 105(2), pp. 1491-1519. doi: 10.1007/s11069-020-04363-4.

Salahudin, S. et al (2020) 'Analysis of Government Official Twitters during Covid-19 Crisis in Indonesia Analysis of Government Official Twitters during Covid-19 Crisis in Indonesia', Talent Development \& Excellence, 12(June), pp. 3899-3915. 
Sarma, M. \& Pais, J. (2008) 'Financial Inclusion and Development: A Cross Country Analysis', In Annual Conference of the Human Development and Capability Association, New Delhi, 168(10-13), pp. 1-30. doi: $10.1002 /$ jid.

Setiati, S. \& Azwar, M. K. (2020) 'COVID-19 and Indonesia', Acta Med Indones - Indones J Intern Med, 52(1), pp. 8489.

Sommer, E. \& Gamper, M. (2021) 'Beyond structural determinism: advantages and challenges of qualitative social network analysis for studying social capital of migrants', Global Networks, 21(3), pp. 608-625. doi: 10.1111/glob.12302.

Wajdi, M. B. N. et al. (2020) 'Education Policy Overcome Coronavirus, A Study of Indonesians', EDUTEC : Journal of Education And Technology, 3(2), pp. 96-106. doi: 10.29062/edu.v3i2.42.

Wu, C. (2021) 'Social capital and COVID-19: a multidimensional and multilevel approach', Chinese Sociological Review. Routledge, 53(1), pp. 27-54. doi: 10.1080/21620555.2020.1814139.

Xiao, Y. \& Torok, M. E. (2020) 'Taking the right measures to control COVID-19', The Lancet Infectious Diseases. Elsevier Ltd, 2019(20), pp. 2019-2020. doi: 10.1016/S1473-3099(20)30152-3.

Zaharah, Kirilova, G. I. \& Windarti, A. (2020) 'Impact of Corona Virus Outbreak Towards Teaching and Learning Activities in Indonesia', Jurnal Sosial E Budaya Syar-i, 7(3), pp. 269-282. doi: 10.15408/sjsbs.v7i3.15104. 